\title{
EFEKTIVITAS AKAD PEMBIAYAAN BAI'AL- WAFA PADA BAITUL MAAL WAT TAMWIL
}

\author{
Kudus \\ Naghfir \\ Lembaga Kajian dan Advokasi Hukum Agraria Malang \\ Jl. Raya Pancir RT 16 RW 5 Desa Pusat Kidul Gondanglegi Malang \\ Email: kudus380@gmail.com; naghfirmkn@gmail.com
}

\begin{abstract}
Akad Bai'al-Wafa is a complementary in the form of loans granted by Baitul Maal Wat Tamwil (BMT) UGT Sidogiri Branch Wonokerto as a buyer (creditor) to its members (sellers) that need funding on condition that the goods sold can be bought back by the seller. Concerning the source of funds used by Baitul Maal Wat Tamwil (BMT) comes from the savings of members for the sake of the smooth customer financing of Bai' al-Wafa. The purpose of this study is to analyze the perspectives of scholars towards the contract implementation of the Ba'i al-wafa in BMT UGT Sidogiri, to determine the effectiveness of Bai' al-Wafa in BMT UGT Sidogiri, and to analyze the benefits of contract Bai' al-Wafa in BMT UGT Sidogiri. This is an empirical legal research using a legal sociological approach. The sources of data in this study are primary and secondary, as for primary data is obtained from the results of interviews with UGT Sidogiri BMT clients, BMT UGT itself and the clergy. While secondary data is obtained from laws and regulations such as Act No. 10 of 1998 on banking, Act No. 21 of 2008 concerning the shari'a banking and shari'a law economy book. The results of this study is that the presence of financing al-Wafa agreement can not be allowed because it is essentially in buying and selling is the perfect of property in a way to avoid usury. While the essentiall in buying and selling is an addition to his home, which is a contract that indicates to be returned with additional terms, either on purpose or not. Then the buyer is free to make goods such guarantees may not be sold to the public. The societies responsif towards BMT UGT is effective because people are easier to obtain financing services.
\end{abstract}

Key words: bai'al-wafa, baitul maal wat tamwi

\begin{abstract}
Abstrak
Akad Bai' al-Wafa merupakan pelengkap yang berbentuk pinjaman yang diberikan oleh Baitul Maal Wat Tamwil (BMT) UGT Sidogiri Cabang Wonokerto, selaku pembeli (pemberi hutang) kepada anggotanya selaku penjual yang memerlukan dana dengan syarat bahwa barang yang dijual tersebut dapat dibeli kembali oleh penjual. Mengenai sumber dana yang dipakai oleh Baitul Maal Wat Tamwil (BMT) dalam memberikan pinjaman kepada anggota berasal dari dana tabungan anggota demi kelancaran nasabah dalam pembiayaan Bai' al-Wafa. Pokok permasalahan yang akan menjadi rumusan masalah dalam penulisan jurnal ini adalah 1 . Bagaimana penerapan akad Bai' al-Wafa di BMT UGT Sidogiri. 2. Bagaiamana efektivitas akad pembiayaan Bai' al-Wafa di BMT UGT Sidogiri dan ke 3. Apa manfaat akad pembiayaan Bai' al-Wafa terhadap perkembangan ekonomi syari'ah di masa akan datang. Tujuan dari penelitian ini untuk menganalisis perspektif ulama terhadap penerapan akad Bai' al-Wafa di BMT UGT Sidogiri, selanjutnya yaitu untuk mengetahui efektivitas Bai' al-Wafa di BMT UGT Sidogiri, serta menganalisis manfaat akad Bai' al-Wafa di BMT UGT Sidogiri. Adapun Jenis metode
\end{abstract}


penelitian yang digunakan untuk membahas penelitian ini yaitu menggunakan jenis penelitian hukum empiris. Dengan menggunakan pendekatan sosiologi hukum (Socio legal). Jenis dan sumber data dalam penelitian ini yaitu primer dan sekunder, adapun data primer di peroleh dari, hasil wawancara dengan para nasabah BMT UGT Sidogiri, pihak BMT UGT sendiri dan para ulama. Sedangkan data sekunder diperoleh dari peraturan perundang-undang. Di antaranya. Undang-undang Nomor 10 tahun 1998 tentang perbankan, Undang nomor 21 tahun 2008 tentang perbankan syari'ah, serta kitab hukum ekonomi syari'ah. Hasil dari penelitian ini ditemukan bahwa Keberadaan akad pembiayaan (Jual beli) Al-wafa, tidak dapat diperkenankan karena hakikatnya dalam jual beli adalah kepemilikan yang sempurna terhadap sebuah barang dengan jalan yang terhindar dari riba. Sementara dalam jual beli hakekatnya adalah suatu tambahan terhadap asalnya. Yaitu suatu akad yang menunjukkan hal tersebut akan dikembalikan dengan syarat tambahan, baik sengaj maupun tidak. Maka pembeli dengan bebas memanfaatkan barang jaminan tersebut tidak boleh dijual dengan pihak manapun. Responsif masyarakat terhadap diterapkannya akad pembiayaan Bai' al-Wafa Baitul Maal Wat Tamwil (BMT) UGT sangat efektif karena masyarakat lebih mudah untuk mendapatkan pelayanan pembiayaan.

Kata kunci: bai'al-wafa, baitul maal wat tamwil

\section{Latar Belakang}

Akad Bai' al-Wafa merupakan akad pembiayaan dalam bentuk pinjaman oleh Baitul Maal Wat Tamwil (BMT) UGT Sidogiri Cabang Wonokerto, selaku pembeli (pemberi hutang) kepada anggotanya selaku penjual yang memerlukan dana dengan syarat bahwa barang yang dijual tersebut dapat dibeli kembali oleh penjual. Mengenai sumber dana yang dipakai oleh Baitul Maal Wat Tamwil (BMT) dalam memberikan pinjaman kepada anggota berasal dari dana tabungan anggota. ${ }^{1}$

Akad Bai' al-Wafa adalah akad jual beli yang dilangsungkan antara dua belah pihak yang diikuti dengan syarat bahwa barang yang jual tersebut dapat dibeli kembali oleh penjual apabila tenggang waktu yang telah ditentukan telah tiba. ${ }^{2}$
Praktek Jual beli semacam ini terbilang unik, bahkan di zaman Rasulullah jual beli semacam ini belum ada. Bai' al-Wafa baru dikenal sekitar abad ke-5 H di Bukhara dan Balkhan.Ketika itu ditengah-tengah masyarakat telah meluas sebuah kenyataan bahwa, si kaya yang mempunyai sejumlah uang tidak mau meminjamkan uangnya kepada orang yang membutuhkan (si miskin). Si kaya baru memberikan pinjaman uang, jika ia diberi hak untuk mengembangkan harta jaminannya. Sementara itu, mereka mengetahui bahwa memanfaatkan barang jaminan oleh penerima jaminan bagian dari riba dan dilarang oleh agama. Akad ini mirip dengan bai' (jual), sehingga jual beli tersebut di perselisihkan oleh para ulama dari aspek hukumnya ${ }^{3}$.

1 Wawancara dengan Yaskur, Manager BMT UGT Sidogiri di Kantor Cabang Wonokerto, 27 Maret 2016.

2 Abbas Arfan, 99 Kaidah Fiqih Muamalah Kulliyah (Tipologi Dan Penerapannya Dalam Ekonomi Islam Dan Perbankan Islam), (Malang: UIN-Maliki Press, 2013), hlm. 131.

3 Yazid Afandi, Fiqih Muamalah dan Implementasinya Dalam Lembaga Keuangan Syariah, (Yogyakarta: Logung Creative Design, 2009), hlm. 64. 
Menurut ulama Hanafiyah ibn taymiyah memandang bahwa jual beli al-Wafa' seperti diatas dipandang tidak syah. Ia menyatakan, bahwa jual beli yang dipraktekkan dalam kehidupan masyarakat seperti yang terjadi setiap hari, yaitu dengan cara jual beli, tukar menukar, dan lain sebagainya. Namun dalam hal ini jual beli yang diperbolehkan yang sudah melalui akad yaitu kesepakatn antara para pihak.

Pembiayaan Murabahah diartikan suatu penjualan barang seharga barang tersebut di tambah dengan keuntungan yang disepakati. ${ }^{4}$ Dimana penerapannya, penjual harus memberi tahu harga produk yang ia beli dan menentukan suatu tingkat keuntungan sebagai tambahannya. Misalnya, pedagang eceran membeli komputer dari harga grosir dengan harga Rp 10.000.000.00- (sepuluh juta rupiah) kemudian ia menambahkan keuntungan sebesar Rp 750.000.00 (tujuh ratus lima puluh ribu rupiah) dan menjual kepada si pemilik dengan harga Rp 10.750.000.00- (sepuluh juta tujuh ratus lima puluh ribu rupiah). Pada umumnya, si pedagang eceran tidak akan memesan dari grosir sebelum ada pesanan dari calon pembeli dan mereka sudah menyepakati tentang lama pembiayaan, besar keuntungan yang akan di ambil pedagang eceran, serta besarnya anggsuran kalau memang dibayar secara angsuran. ${ }^{5}$

Berdasarkan hasil penelitian di lapangan, seorangnasabahmeminjammodaluntukusaha, dengan menjual sepeda motornya kepada Baitul maal wat tamwil (BMT) UGT Sidogiri dan dibeli dengan $50 \%$ (lima puluh persen) dari harga pasar, pihak baitul maal wat tamwil (BMT) berjanji tidak akan menjual kendaraan tersebut kepada pihak manapun selain kepada nasabah (penjual). Setelah sepeda motor tersebut menjadi milik baitul maal wat tamwil (BMT) UGT Sidogiri (pembeli), pembeli menyerahkan dan menyewakan kendaraan tersebut kepada nasabah (penjual), nasabah mensepakati akan membayar uang sewa dan angsuran pembiayaan dalam waktu yang sudah disepakati, setelah masa tenggangnya habis, maka penjual dapat membeli kembali sepeda motornya sesuai kesepakatan di awal.

Peristiwa hukum tersebut, terjadi pada nasabah Baitul Maal Wat Tamwil (selanjutnya disebut BMT) UGT Sidogiri. Di mana nasabah ingin melakukan pinjaman (pembiayaan) untuk modal usahanya. Pihak BMT akan memberikan pinjaman kepada nasabah yang Perspektif dan akad yang digunakan oleh pihak BMT UGT Sidogiri adalah akad Bai'al-Wafa. Dimana nasabah menjual sepeda motornya dengan merk Honda Supra seharga 6.000.000 (enam juta rupiah) akan tetapi pihak BMT hanya mau membeli 50\% (lima puluh persen) dari harga pasar, sehingga setelah ditaksir oleh pihak BMT harganya menjadi Rp 3.069.000 (tiga juta enam puluh Sembilan ribu rupiah) plus marginnya sebesar 2,3\% (dua koma tiga persen), untuk pengembalian pinjamannya. 
Pembayaran angsuran dilakukan dengan cara dicicil selama 1 (satu) tahun sesuai dengan waktu yang telah disepakati, dan setelah cicilannya lunas nasabah dapat membeli kembali sepeda motornya dengan harga yang sama yakni $50 \%$ (lima puluh persen) dari harga pasar, sesuai dengan kesepakatan yang terjadi di awal akad.

Motivasi BMT UGT Sidogiri cabang Wonokerto menerapkan Bai' al-Wafa dikarenakan Baitul Maal Wat Tamwil (BMT) bukan hanya sebagai lembaga sosial tetapi BMT juga sebagai lembaga profit oriented yang juga ingin mendapatkan keuntungan, akad pembiayaan Bai' al-Wafa sering digunakan para nasabah BMT yang ingin melakukan pembiayaan, karena akad ini dianggap menguntungkan dan paling mudah. Bagi pihak BMT, jika dibandingkan dengan sistem bagi hasil (mudharabah), produk Bai' al-Wafa cukup memudahkan, mark up pembiayaan tersebut dapat diterapkan sedemikian rupa sehingga memastikan bahwa BMT dapat memperoleh keuntungan, pembiayaan tersebut juga menjauhkan diri dari ketidak pastian yang ada pada pendapatan usaha-usaha dengan sistem profit dan loss sharing.

\section{Pembahasan}

A. Penerapan Akad Bai' Al-Wafa di BMT UGT Sidogiri Cabang Wonokerto

Penerapan akad pembiayaan Bai' al-Wafa hal yang pertama dilihat oleh BMT terhadap nasabahnya adalah karakter dan loyalitas anggota. Karakter dan loyalitas tersebut dapat dilihatdari kejujuran dan kesungguhan anggota dalam melengkapiatau persyaratanpersyaratan yang diajukan oleh Baitul Maal Wat Tamwil (BMT) UGT Sidogiri Cabang Wonokerto dalam melakukan pembiayaan.

Ketentuan pembiayaan Bai' al-Wafa di BMT UGT Sidogiri Cabang Wonokerto sebagai berikut:

1. BMT menyediakan dana yang diperlukan.

2. BMT meminta peminjam untuk membeli kembali barang yang dijualkepada pihak BMT.

3. Pengembalian pinjaman dilakukan dengan cara mengangsur tiap bulanpada pihak BMT.

Presentase yang digunakan oleh BMT UGT Sidogiri Cabang Wonokerto adalah sebesar $50 \%$ (lima puluh persen) dalam menentukan harga beli dari barang jaminan yang akan di jual kepada pihak BMT, dengan ketentuan margin sebesar $2.3 \%$ (dua koma tiga persen).

\section{Sumber dana dan syarat pada akad Bai' al-Wafa}

a. Sumber Dana pada akad Bai'al-Wafa Baitul Maal Wat Tamwil (BMT) UGT Sidogiri Cabang Wonokerto sangat selektif dan berhati-hati dalam menyalurkandananya kepada masyarakat khusunya yang berupa pembiayaan Bai' al-Wafa. Sumber dana Bai' al-Wafa di BMT UGT Sidogiri Cabang Wonokerto berasal dari dana tabungan anggota BMT. 
b. Syarat pada akad Bai' al-Wafa

Setiap orang yang akan mengajukan pembiayaan Bai' al-Wafa di BMT UGT Sidogiri Cabang Wonokerto harus memenuhi persyaratan sesuai dengan yang dijelaskan sebelumnya. Selain itu ada persyaratan lain yaitu anggota yang melakukan pinjaman Bai' al-Wafa diminta untuk membeli kembali barang yang telah dijual pada pihak $\mathrm{BMT}^{6}$.

\section{Analisis prespektif syariah terhadap penerapan akad pembiayaan Bai'al-Wafa}

a. Latar belakang munculnya Bai' al-Wafa Jual beli jenis ini yakni Bai' al-Wafa belum di kenal pada zaman nabi. Ia baru dikenal pada sekitar pertengahan abad ke-V Hijriyah di Bukhara dan Balkhan. Ketika itu di tengahtengah masyarakat telah meluas sebuah kekayaan bahwa, si kaya yang mempunyai sejumlah uang tidak mau meminjamkan uangnya kepada orang yang membutuhkan (si miskin) yang sedang membutuhkan. Si kaya baru mau memberi pinjaman uang, jika ia diberi hak untuk mengembangkan harta jaminannya. Sementara itu, mereka tahu bahwa memanfaatkan barang jaminan oleh penerima jaminan termaksud bagian dari riba dan dilarang oleh agama berdasarkan hadits nabi.

$$
\text { ابرلا وهف قعفنملا رخ ضرق لك }
$$

Artinya : "setiap utang yang di barengi dengan pemanfaatan (untuk pemberian utang) adalah riba". (HR. al-Bukhari).

6 Ibid.

7 (HR. Al-Imam Al-Timidzi).
Maka kemudian munculah akad Bai' al-Wafa ini. Dilihat dari harta yang menjadi jaminan harus kembali kepada pemilik harta, maka akad ini mirip dengan Rahn. Namun jika dilihat dari sisi harta yang menjadi jaminan tersebut bebas untuk di ambil manfaatnya oleh penerima jaminan, akad ini mirip dengan bai'. Sehingga jual beli ini merupakan jual beli khusus yang memang di perselisihkan oleh ulama dari aspek hukumnya yakni tentang syarat, dimana pihak penjual tidak boleh menjual barang yang dibeli kepada pihak manapun kecuali pihak penjual pertama. Hal inilah yang menjadi perselisihan sebab kalau merujuk kepada syarat jual beli syarat seperti itu tidak ada.

\section{Analisis perspektif ulama terhadap penerapan akad pembiayaan $B a i{ }^{\prime}$ al-Wafa Di Baitul Maal Wat Tanwil (BMT) UGT Sidogiri Cabang Wonokerto}

\begin{abstract}
"Sesungguhnya ulama adalah pewaris para nabi, sungguh para nabi tidak mewariskan dinar dan dirham, sungguh mereka hanya mewariskan ilmu maka barang siapa mengambil warisan tersebut, ia telah mengambil bagian yang banyak ${ }^{7}$
\end{abstract}

Menurut Romadhon Khotib, Bai'alWafa dari aspek hukumnya masih terdapat pertentangan, disebabkan dalam akad tersebut terdapat penggabungan tiga akad. Menurut beliau ada beberapa pendapat mengenai Bai' al-Wafa ini. Menurut Mazhab Hambali dan 
Maliki cenderung tidak memperbolehkan karena adanya penggabungan tiga akad, yang pertama, ijarah, kedua rahn, dan bai' (jual beli) itu sendiri. Sehingga ini dianggap kurang sesuai. Akan tetapi menurut mazhab hanafi, hal itu merupakan hal yang bemanfaat untuk menghindari riba sehingga fiqih mazhab memperbolehkan hal tersebut. Dan menurut koridor fiqih, kita boleh mengikuti mazhab yang 4 itu. Yang dilarang adalah talfeq'. Talfeq' itu mencampur adukkan beberapa mazhab dalam satu masalah. ${ }^{8}$

Begitu juga dengan Bapak Nursalim yang sependapat dengan beliau yang memandang Bai' al-Wafa yang masih di perselisihkan bagi kalangan beberapa ulama. Sebagaimana yang disampaikan beliau bahwa Bai' al-Wafa memang di perdebatkan antara ulama. Para ulama syafi'iah, hambali dan maliki yang tidak sepakat terhadap hal tersebut.Tetapi ulama hanafiyah itu memperbolehkan dengan dalih ikhthisan supaya terhindar dari riba. ${ }^{9}$

Beberapa ulama berpendapat bahwa Bai' al-Wafa masih di pertanyakan dari segi hukumnya.Sebagaimana yang di ungkapkan bahwa Bai' al-Wafa banyak di perselisihkan oleh banyak ulama. Mereka berpendapat untuk mengikuti imam yang memperbolehkan saja, seperti imam hanafiyah tersebut yang mengembangkan akad tersebut. Mengikuti mahzab yang empat tersebut diperbolehkan, yang tidak boleh adalah Fiiqadliyah Wahidah dalam satu qodliyah. Contohnya, wudhunya ikut imam syafi'i shalatnya imam hanafiyah itu juga boleh, yang tidak boleh mencampurkan beberapa mazhab dalam satu persoalan. Shalatnya caranya ikut syafi'iah batalnya shalat ikut hanafiyah, itu yang tidak boleh, kalau wudhunya ikut syafi'i, shalatnya ikut hanafiyah penuh sak batal-batal shalat. Itu boleh karena satu qoddiyah. ${ }^{10}$

Ungkapan yang sama juga di sampaikan oleh Bapak Moch Ichsan tentang hukum bai' al-wafa' yang menjadi perselisihan diantara beberapa ulama. Beliau menyampaikan bahwa Bai' al-Wafa banyak diperselisihkan oleh beberapa ulama salah satunya tentang syarat tersebut, tetapi menurut beliau indi'qotil Madzaaib (pindah imam). Dengan catatan hanya berlaku dalam satu qoddiyah hukum itu. Contohnya: Bab mengenai shalat, bab tentang shalat itu kita mengikuti imam hanafi padahal kita termaksud ashabul asy-syafi'iyah, maka itu boleh dengan catatan seluruh yang berkaitan dengan shalat, termaksud wudhunya, batal wudhunya harus mengikuti imam hanafi. ${ }^{11}$

Pendapat-pendapat tersebut dapat dipersepsikan bahwa kita boleh mengikuti empat mazhab tersebut asal tidak mencampur adukan dari empat mazhab tersebut dalam 1

\footnotetext{
8 Wawancara dengan Romadhon Khotib, Kantor Cabang Nadlatul Ulama, 27 Mei 2016.

9 Wawancara dengan Nursalim, Pondok Pesantren Raudatul Ulum Gondang Legi, 27 Mei 2016.

10 Wawancara dengan Romdhon dan Drs. Nursalim, Khotib, 27 Mei 2016.

11 Wawancara dengan KH. Moch Ichsan, di Kediamannya Gondang legi, 27 Mei 2016.
} 
(satu) masalah ${ }^{12}$. Berpindah mazhab fiqih itu diperbolehkan dalam kondisi dan ketentuan yang khusus, tujuannya untuk memudahkan ummat islam karena inilah karakter ajaran islam. Nabi Muhammad SAW di utus juga untuk mempermudah dan bukan untuk mempersulit ummatnya. Sabagaimana dengan akad Bai' al-Wafa tujuannya mempermudah anggota (nasabah) dalam melakukan pembiayaan untuk usahanya atau keperluan mendesak.

Dalam Bai' al-Wafa ada syarat yang mengikat, yakni pihak kedua tidak boleh menjual barang jaminan kepada siapapun kecuali kepada pihak pertama (penjual). Akan tetapi bila kita merujuk kepada hadits jual beli yang dibarengi dengan syarat tersebut termasuk jual beli yang dilarang syara'. Hal ini sesuai dengan sebuah hadits, "Rasulullah SAW melarang jual beli yang dibarengi dengan syarat." 13 Maka dari itu syarat ini yang menjadi perselisihan diantara ulamaulama.Akan tetapi para informan- informan dalam penelitian ini. Memiliki pandangan yang berbeda dalam menyikapi syarat yang ada di Bai'al-Wafa.

Dari pendapat-pendapat tersebut, dapat di pahami oleh peneliti bahwa dalam praktek Bai' al-Wafa tersebut sebaiknya syarat tersebut di ucapkan di luar akad, karena jika merujuk kepada syarat jual beli tidak boleh ada syarat seperti itu. Maka caranya harus ditata pemikirannya atau diarahkan, jangan sampai terucap dalam satu akad, karena Mazhab Syafi'i mengatakan bahwa kalau muhtadol ardi itu adalah fisufil ardi dalam satu transaksi maka itu termaksud riba. Akan tetapi bila tidak dalam satu transaksi atau dalam satu akad maka itu di perbolehkan. Dengan cara, ketika ada akad seperti itu tidak boleh memakai syarat atau ucapan yang tidak boleh menjual barang tersebut kepada orang lain atau barang tersebut harus kembali ke pemilik pertama. Maka syarat seperti itu diucapkan di luar akad atau cukup dengan saling mengerti antara keduanya tentang barang tersebut.

Ketika ada syarat seperti itu di akad Bai' al-Wafa, memperbolehkan akad Bai' al-Wafa tersebut di terapkan. Sementara tentang boleh tidaknya akad Bai' al-Wafa diterapkan, informan yang pertama yakni Bapak Romadhon Khotib memandang boleh saja Bai' al-Wafa di terapkan asal dalam penerapannya seperti yang di jelaskan oleh beliau bahwa Bai' al-Wafa dengan cara seperti itu bukan menjadi persyaratan tapi persyaratan dibicarakan dibelakang tidak disebutkan dalam akad tersebut. Seperti dasarnya yang seperti ini, yang pertama "setiap transaksi yang menjadi persyaratan itu, kalau persyaratan fishohibul ardhi maka dia menjadi riba. Tetapi kalau fii ghairo sahibul ardhi (di luar akad) maka itu

12 Mencampur antara dua pendapat dalam satu Qodliyah (masalah) baik sejak awal, pertengahan dan seterusnya, yang nantiya dari dua pendapat itu akan menimbulkan satu amaliyah yang tak pernah di katakana oleh orang berpendapat. Ahmad Baidlowi, "Initisari amaliyah ulama fiqih", http://restuandrian.blogspot.com/2011/12/ pengertian-dan-hukum-taqlid.html, diakses 26 Mei 2016.

13 HR. Muslim. An-Nasa'i, Abu Dawud, At-Tirmidzi, dan Ibnu Majah. 
menjadi sah. Dan yang kedua jasikun hoiron riba. Jadi sah-sah saja diterapkan. ${ }^{14}$

Begitu juga dengan pendapat Bapak Nursalim yang juga sependapat bahwa Bai' al-Wafa bisa di terapkan. Menurut beliau sah-sah saja akad Bai' al-Wafa diterapkan asal aspek kemaslahatannya terjaga dan tidak muncul pihak yang dirugikan secara hakiki ${ }^{15}$.

Pendapat di atas juga sejalan dengan pandangan Bapak Bahrul yang memperbolehkan Bai' al-Wafa diterapkan. Sebagaimana yang di sampaikan oleh beliau.

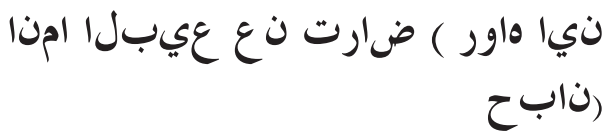

Artinya: sesungguhnya jual beli ini hanya sah jika suka sama suka" (Riwayat Ibnu Hibban)

Prinsip dasar yang paling utama dari muamalah itu saling rela namun mengapa terkesan longgar, ini untuk memberikan seluas-luasnya kesempatan kepada pelakupelaku syariah itu, agar tidak terjebak atau terjatuh kepada riba "Allah menghalalkan jual beli dan mengharamkan riba" maka terjadilah hilatul hukmi (rekayasa hukum). Bai' al-Wafa ini termasuk rekayasa hukum.

Begitu juga dengan informan ke empat Moch Ichsan yang memandang Bai' al-Wafa boleh diterapkan sebagaimana yang di ungkapkan bahwa beliau memperbolehkan hak tersebut. Syarat yang tidak boleh di jual kepada pihak manapun tidak diucapkan didalam satu transaksi tapi di luar transaksi. ${ }^{16}$

Dari beberapa pendapat tersebut, dapat di simpulkan Bai' al-Wafa boleh diterapkan, yakni dengan imam yang memperbolehkan atau dengan pendapat yang kedua yakni syarat yang tidak boleh di jual kepada pihak manapun tidak di ucapkan dalam satu transaksi tersebut tapi di ucapkan di luar transaksi atau di ucapkan di lain hari. Dan dalam penerapannya aspek kemaslahatannya juga terjaga, karena dasar jual beli tersebut adalah saling suka sama suka.

Jika Bai' al-Wafa boleh diterapkan, bagaimana jika Bai' al-Wafa di gunakan untuk pembiayaan.

Menurut Bapak Romadhon Khotib akad Bai' al-Wafa bisa di gunakan untuk pembiayaan dengan beberapa alasan yang di ungkapkan oleh beliau. Sebagai berikut bahwa bisa saja, dengan cara yang seperti mazhab syafi'i yakni syarat yang mengikat tadi bukan sebagai syarat utama dalam transaksi satu akad. Akan tetapi lebih ditekankan kepada perasaan pribadi orang itu saja.Tidak terucap dalam transaksi seperti itu. Kita ambil jalan tengah, kita tidak menyalahkan dengan apa yang di gariskan oleh imam hanafi. Tetapi juga mewakili mazhab syafi'i. ${ }^{17}$

Berbeda dengan Bapak Nursalim yang memandang berbeda tentang Bai' al-Wafa yang di gunakan untuk pembiayaan. 
Sebagaimana pendapat beliau.bahwa boleh saja, karena akad Bai' al-Wafa dikembangkan oleh mazhab hanafiyah supaya masyarakat terhindar dari riba. Dan dinggapnya akad tersebut hal yang simpel dalam melakukan transaksi. Apalagi untuk pembiayaan. Menurut beliau indiqotil madzaaib (pindah mazhab) yang diperbolehkan atau disepakati oleh ulama hanafiyah. ${ }^{18}$

Berbeda dari sudut pandang Bapak Nursalim dengan informan yang pertama, dimana Bapak Nursalim memandang BMT UGT Sidogiri yang menerapkan akab Bai' al-Wafa sebagai berikut.

"Bagus untuk solusi. Daripada
melakukan transaksi ribawi,
lebih baik memakai Bai' al-Wafa.
Kalau ribawi semua ulama tidak
mensepakati, kalau Bai'al-Wafa kan
di sepakati oleh mazhab hanafiyah,
karena kita boleh mengikuti dari
empat mazhab tersebut. ${ }^{19}$

Pendapat tersebut juga sejalan dengan pendapat Bapak Bahrul Ulum. Sebagaimana pendapat beliau bahwa BMT dalam prakteknya seperti itu, beliau berpandangan berprasangka baik terhadap BMT. Karena beliau bukan alumni sidogiri tapi alumni Lirboyo, di Lirboyo tidak di kenal seperti itu. Kalau di Sidogiri seperti itu beliau su'uzon saja, mungkin BMT mempunyai dasarnya yakni mengikuti Mazhab Hanafiyah, jadi boleh-boleh saja kalau ada imam yang mempertanggung jawabkan, saya teringat di Fathul Mu'in itu ada bahasa seperti ini "seandainya ada ami (orang awam) ${ }^{20}$ yang mempraktekkan suatu perbuatan, sekalipun ia tidak tahu dasarnya. Asalkan tepat dengan salah satu pendapat imam yang bisa di pertanggung jawabkan yakni empat imam tersebut. Ia masih di maafkan. Jadi akad Bai' al-Wafa tersebut boleh diterapkan dengan dasar mengikuti imam hanafiyah, karena dalam koditor fiqih kita boleh berpindah mazhab fiqih dalam kondisi dan ketentuan yang khusus. Tujuannya untuk mempermudah masyarakat dalam bermuamalah. Bai' al-wafa bertujuan dalam rangka menghindari dari riba, jadi menurut beliau boleh saja Bai' al-Wafa digunakan oleh BMT UGT Sidogiri. ${ }^{21}$

Begitu juga dengan Bapak Moch Ichsan yang berpandangan sama dengan kedua informan kedua dan ketiga dalam memandang BMT UGT Sidogiri yang menerapkan Bai' al-Wafa untuk pembiayaan. Menurut beliau bahwa beliau mendukung pemakaian akad tersebut, seperti tujuan di bentuknya akad ini adalah untuk menghindari masyarakat dari hukum haram yakni riba. Tapi masukan dari beliau untuk mencobal syarat tersebut tidak di ucapkan dalam satu transaksi. Cukuplah saling mengerti saja atau diucapkan di luar akad. $^{22}$

18 Wawancara dengan bapak Nursalim, Pondok Pesantren Raudatul Ulum Gondang Legi, 27 Mei 2016.

19 Wawancara dengan Nursalim, di Pondok Pesantren Raudatul Ulum Gondang Legi, 27 Mei 2016.

20 Orang awam itu seluruh orang yang hidup setelah 400 H. Kan pintu hijriyah ditutup. Menurut kesepakatan mayoritas ulama, di sepakati setelah 400 tahun kebawah sampai sekarang dianggap ami (awam).

21 Wawancara dengan Bahrul Ulum, di Kediamannya Gondang Legi, 27 Mei 2016.

22 Wawancara dengan KH. Moch Ichsan, di Gondang Legi, 27 Mei 2016. 
Pendapat informan (Ulama) yang pertama memberikan gambaran bahwa BMT UGT Sidogiri menurut pandangan informan bahwa dalam prakteknya tidak menjalankan sesuai dengan syariah. Dimana menurut pengalaman beliau, ketika pinjaman semakain besar maka pengembaliannya lebih besar juga padahal dalam administrasinya sama dengan pinjaman yang lebih rendah. Dari pengalaman tersebutlah beliau menyimpulkan bahwa tidak yakin jika BMT menjalankan sesuai dengan syariah. Berbeda dengan informan yang lainnya mereka setuju dengan BMT yang menggunakan akad tersebut, dimana mereka memandang akad tersebut bagus untuk di terapkan karena solusi untuk menghindari riba begitu juga dengan informan yang lainnya meraka sepakat dengan BMT yang menerapkan akad tersebut asal di dukung dengan dasar yang kuat dan juga memberikan masukan untuk BMT dimana sebaiknya syarat tersebut tidak diucapkan pada saat akad akan tetapi di luar akad.

Pembiayaan dengan menggunakan akad Bai' al-Wafa merupakan produk baru dari BMT UGT Sidogiri Cabang Wonokerto. Bai' al-Wafa merupakan akad jual beli bersyarat. Dimana penjual (nasabah) menjual barangnya pada pembeli (pihak BMT) dimana barang yang di jual tersebut tidak boleh dijual kepihak manapu kecuali kepada pihak pertama, sehingga pihak pertama dapat membeli kembali barang tersebut, karena penjual masih membutuhkan barang tersebut. Produk ini diberikan kepada nasabah untuk kebutuhan usaha atau untuk kebutuhan mendesak lainnya. Sumber dana dalam akad Bai' al-Wafa di BMT UGT Sidogiri Cabang Wonokerto berasal dari dana tabungan anggota BMT.

Ketentuan pembiayaan dengan akad Bai' al-Wafa di BMT UGT Sidogiri Cabang Wonokerto sebagai berikut:

1. BMT menyediakan dana pinjaman, selaku pembeli (Debitur)

2. BMT meminta penjual untuk menjual barang jaminan seharga 50\% (lima puluh persen) dari harga pasar

3. Pengembalian pinjaman dilakukan dengan cara mengangsur tiap bulansebesar jumlahangsuran yang sudah dihitung pihak BMT, yang berasal darijumlah pinjaman, margin 2,3\% (dua koma tiga persen) dan biaya sewa (ujrah) tiap bulan

Dalam teorinya, Bai' al-Wafa adalah jual beli yang dilangsungkan antara dua belah pihak, diikuti dengan syarat bahwa barang yang dijual tersebut dapat dibeli kembali oleh penjual apabila tenggang waktu yang ditentukan telah tiba. BMT UGT Sidogiri Cabang Wonokerto menerapkan akad Bai' al-Wafa, dimana BMT membeli barang jaminannya seharga 50\% (lima puluh persen) dari harga pasar.

Karena akad Bai' al-Wafa sejak semula ditegaskan sebagai jual beli, maka pembeli dengan bebas memanfaatkan barang itu. Hanya saja pembeli tidak boleh menjual barang jaminan itu kepada orang lain selain kepada penjual semula, karena barang jaminan yang berada di tangan pemberi utang 
merupakan jaminan utang selama tenggang waktu yang disepakati itu. Pembiayaan Bai' al-Wafa ini adalah pembiayaan bagi anggota yang ingin melakukan pinjaman untuk kebutuhan usahanya ataupun untuk keperluan lainnya berdasarkan prinsip jual beli bersyarat tersebut.

Alasan BMT membeli harga barang jaminan seharga 50\% (lima puluh persen) dari harga pasar, hal ini bertujuan untuk mengurangi resiko apabila ada nsabah yang melakukan kecurangan, selain itu BMT juga sebagai lembaga profit oriented yang juga ingin mendapatkan keuntungan, dalam hal ini pada akad Bai' al-Wafa.

Menurut Jalan fikiran ulama Mazhab Hanafi dalam memberikan justifikasi terhadap Bai' al-Wafa didasarka pada istihsan 'urfi (menjustifikasi suatu permasalahan yang telah berlaku umum dan berjalan baik di tengahtengah masyarakat). Akan tetapi ulama fiqih lainnya tidak bias melegalisasi bentuk jual beli ini, alasan mereka adalah:

1. Dalam suatu akad jual beli tidak dibenarkan adanya tenggang waktu, karena jual beli adalah akad yang mengakibatkan perpindahan hak milik secara sempurna dari penjual ke pembeli.

2. Dalam jual beli tidak boleh ada syarat bahwa barang yang dijual itu harus dikembalikan oleh pembeli ke penjual semula, apabila ia telah siap mengembalikan uang seharga jual semula ${ }^{23}$.
3. Bentuk jual beli ini tidak ada di zaman Rasulullah SAW maupun di zaman sahabat.

4. Jual beli ini merupakan hilah yang tidak sejalan dengan maksud syara' dan persyariatan jual beli ${ }^{24}$.

Hasil pandangan ulama yang menjadi informan dalam penelitian mempunyai pandangan yang sama dalam memahami Bai' al-Wafa dimana menurut pendapat mereka Bai' al-Wafa seperti Rahn. Karena dilihat harta yang menjadi jaminan harus kembali lagi kepada pemilik harta. Namun jika dilihat dari sisi harta bahwa harta yang menjadi jaminan tersebut untuk di ambil manfaatnya oleh penerima jaminan hal tersebut seperti Bai'. Dalam Kitab Raddul Muhtar, ibnu Abidin juga demikian dalam pemanfaatan objek akad (barang yang di jual). Statusnya hampir sama dengan Rahn, dan hukumnya pun sama dengan akad Rahn. Hanya saja akad tersebut merupakan perkembangan dari rahn, yang kemudian menjadi akad Bai' al-Wafa yang berubah sesuai dengan kebutuhan masyarakat.

Ulama-ulama fiqih memperselisihkan tetang syarat yang ada di Bai'al-Wafa dimana barang yang di jual tersebut tidak boleh di jual kepada pihak manapun kecuali kepada pihak yang pertama, artinya barang yang dijual tersebut akan kembali lagi kepada pihak yang menjual pertama jika tenggang waktu yang telah di tentukan pada saat perjanjian. Dan hal ini bila merujuk kepada hadits tidak boleh ada syarat

23 HR. Muslim, An-Nasa'I, Abu Daud, At-Tirmizi, Ibnu Majah. 
seperti ulama-ulama yang menjadi informan dalam penelitian tersebut. Juga sepakat dengan ulama-ulama terdahulu yang memperselisihkan tentang syarat-syarat Bai' al-Wafa tersebut.

Alasan yang dipakai untuk mengesahkan akad Bai' al-Wafa oleh Imam Hanafi adalah istihsan urfi, ialah menjustifikasikan suatu permasalahan yang telah berlaku umum dan berjalan dengan baik di tengah masyarakat dan tidak mengandung mudharat. Sehingga dianggap sah.

Menurut ulama-ulama fiqih yang menjadi informan dalam peneliti tersebut. Kurang sepakat tentang syarat yang ada di Bai'al-Wafa yakni barang yang menjadi jaminan, harus kembali jika tenggang waktu yang telah di tentukan telah tiba. Sedangkan jika merujuk kepada syarat jual beli dan hadits tidak ada syarat yang mengikat seperti itu, sebab jual beli adalah kepemilikan sempurna. Maka beberapa informan memberi jalan tengah dengan cara syarat yang tidak boleh menjual barang jaminan kepada orang lain kecuali kepada pihak pertama (penjual pertama) tidak diucapkan di dalam satu transaksi atau dalam satu akad tersebut. Karena mazhab syafi'i mengatakan bahwa kalau muhtadol ardi itu adalah fisufil ardi dalam satu transaksi maka itu yang termasuk riba. Tapi kalau tidak dalam satu transaksi atau dalam satu akad, maka itu diperbolehkan. Maka dengan cara, ketika akad tidak memakai syarat atau ucapan yang tidak diperbolehkan menjual barang jaminan kepada orang lain kecuali kepada penjual pertama, diucapkan di luar akad atau di ucapkan dilain waktu. Dan juga dengan saling mengerti saja antara kedua belah pihak terhadap barang tersebut.

Ada juga ulama yang berbeda pendapat, dimana cukup dengan intaqil madzaaib (pindah mazhab) saja, yakni mengikuti mazhab yang memperbolehkan yakni mazhab hanafi. Sehingga akad tersebut bisa di terapkan untuk pembiayaan yang sekarang dipergunakan oleh BMT UGT Sidogiri Cabang Wonokerto.

\section{Efektifitas Akad pembiayaan Bai' al-Wafa di Baitu Maal Wat Tamwil (BMT) UGT Sidogiri Cabang Wonokerto}

Realisasi perhitungan pembiayaan Bai' al-Wafa di BMT UGT Sidogiri Cabang Wonokerto. Realisasi akad Bai' al-Wafa di BMT UGT Sidogiri Cabang Wonokerto adalah gambaran nyata pada anggota yang melakukan akad pembiayaan Bai' al-Wafa. Pada penerapan akad Bai' al-Wafa, dimana ada anggota yang bernama Bapak Sulaiman, beliau sudah menjadi anggota BMT UGT Sidogiri Cabang Wonokerto selama 2 (dua) tahun akan melakukan pembiayaan dengan jaminan sepeda motor Mio Tahun 2012. Sebelum anggota melakukan pembiayaan, BMT menjelaskan Produk pembiayaan yang dimiliki oleh BMT diantaranya ada produk pembiayaan Qord Al-hasan, Bai' bitsmanil 'ajil, murabahah, musyarakah, mudharabah, dan Bai' al-Wafa dengan penjelasan dan pengarahan tentang masing-masing akad tersebut, anggota lebih tertarik dengan produk Bai' al-Wafa, karena menurut mereka akad 
ini lebih praktis dan lebih mudah juga ${ }^{24}$. Dimana anggota cukup menjual sepeda motor tersebut, tetapi sepeda motor tersebut, tetap bisa dibeli kembali sesuai dengan kesepakatan di awal dan juga anggota masih menggunakan sepeda motor tersebut karena pihak BMT menyewakan kepada anggota tersebut.

Motor Mio Tahun 2012 dihargai oleh anggota seharga Rp. 7.500.000,- (tujuh juta lima ratus ribu rupiah) akan tetapi BMT hanya mau membeli seharga 50\% (lima puluh persen) dari harga pasar. Maka perhitungannya yang dilakukan BMT sebagai berikut. Dimana harga motor Rp. 7.500 .000 (tujuh juta lima ratus ribu rupiah), dikalikan dengan presentase yang sudah di tentukan oleh BMT yaitu $50 \%$ (lima puluh persen) dari harga pasar. Maka harga motor menjadi Rp. 3.750 .000 (tiga juta tujuh ratus lima puluh ribu rupiah) yang akan dibeli oleh BMT tersebut ${ }^{25}$.

\section{Efektifitas Akad pembiayaan}

\section{Bai' al-Wafa di Baitul Maal Wat Tamwil (BMT) UGT Sidogiri CabangWonokerto}

Berdasarkan penelitian yang dilakukan penulis dikaitkan dengan teori efektifitas bahwa praktek akad pembiayaan $B a^{\prime} u l$ wafa yang ada di Baitul Maal Wat tamwil (BMT) UGT Sidogiri Cabang Wonokerto.

Berkaitan dengan Pendapat Anthony Allot sebagaimana kutipan Salim, HS dan
Erlies Septiana Nurbani tentang efektifitas hukum. Ia mengemukakan bahwa:

"Hukum akan menjadi efektif jika tujuan keberadaan dan penerapannya dapat mencegah perbuatan-perbuatan yang tidak diinginkan dapat menghilangkan kekacauan. Hukum yang efektif secara umum dapat membuat apa yang dirancang dapat diwujudkan. Jika suatu kegagalan, maka kemungkinan terjadi pembetulan secara Menurut gampang jika terjadi keharusan untuk melaksanakan atau menerapkan hukum dalam suasana baru yang berbeda, hukum akan sanggup menyelesaikannya."26

Sesuai dengan konsep Anthony Allot tentang efektifitas hukum tersebut dititik beratkan pada perwujudan hukum dan pelaksanaannya dimasyarakat. Hukum yang efektif secara umum dapat membuat apa yang dirancang dapat diwujudkan dalam kehidupan sosial kemasyarakatan.

Tujuan hukum adalah harus menjamin sebanyak mungkin kebahagiaan kepada sebanyak mungkin manusia. Mengingat bahwa manusia itu sepanjang hidupnya selalu diancam bahaya, sehingga membutuhkan perlindungan dalam bentuk hukum, maka hukum dibentuk bertujuan untuk mengatur masyarakat dan melindungi kepentingan manusia dan masyarakat serta menjaga ketertiban dalam masyarakat. ${ }^{27}$

24 Wawancara dengan Khoiron R.Z. Bagian, Teler di BMT UGT Sidogiri, 27 Mei 2016.

25 Wawancara dengan Khoiron R.Z. Bagian, Teler di BMT UGT Sidogiri, 30 Mei 2016.

26 Salim HS dan Erlies Septiana Nurbani, Penerapan Teori Hukum Pada Penelitian Tesis dan Disertasi, (Jakarta: Raja Grafindo Persada, 2014), hlm. 302.

27 Sudikno Mertokusumo, Teori Hukum, (Yogyakarta: Universitas Atma Jaya Yogyakarta, 2011), hlm. 75. 
Pelaksanaan hukum dapat terjadi secara sukarela antar manusia, hukum adalah kaidah sosial untuk mengatur perilaku manusia atau masyarakat agar kepentingankepentingannya terlindungi, karena kepentingan-kepentingannya selalu diganggu oleh sesamanya atau alam sepanjang masa. Setiap manusia pada dasarnya berkepentingan bahwa hukum itu dilaksanakan oleh setiap manusia karena dengan demikian kepentingan dirinya akan terlindungi juga. Oleh karena itu, hukum sebagai perlindungan kepentingan manusia harus dihayati, dilaksanakan, dan ditegakkan.

Selain itu sebagaimana kutipan Salim HS dan Erlies Septiana Nurbani menurut pendapat Soerjono Soekanto mengemukakan 5 (lima) faktor yang harus diperhatikan dalam penegakan hukum, bahwa penegakan hukum merupakan kegiatan menyerasikan hubungan nilai-nilai yang diwujudkan kedalam kaidah yang mantap dan mengejawantahkan serta sikap tindak sebagai rangkaian penjabaran nilai tahap akhir, untuk menciptakan, memelihara, dan mempertahankan kedamaian dalam masyarakat. Adapun 5 (kelima) faktor tersebut sebagai berikut:

1. Faktor Hukum atau Undang-Undang;

2. Faktor Penegak Hukum;

3. Faktor Saran atau Fasilitas;

4. Faktor Masyarakat; dan

5. Faktor Kebudayaan. ${ }^{28}$

Maka untuk berlaku efektif hukum harus memenuhi 5 (kelima) faktor tersebut dalam penerapannya dimasyarakat, penegakan hukum diselenggarakan adalah untuk menjamin kepastian hukum, serta menciptakan kedamaian dimasyarakat, sehingga norma hukum tersebut secara sukarela akan ditaati dan dilaksanakan dalam sosial kemasyarakatan.

Berlakunya hukum tentang adanya Akad Pembiyaan Bai' al Wafa tersebut dalam konteks efektivitas berlakunya, yaitu menunjukkan suatu yang signifikan positif yang terjadi di masyarakat. Kultur yang mayoritas muslim mempunyai korelasi yang bagus terhadap keefektifan keberadaan hukum tersebut. Sarana dan prasarana dalam mewadahi praktek pembiayaan yang berbasis syari'ah merupakan bentuk maslahah mursalah lil ummat, sehingga antusias masyarakat terhadap produk tersebut benarbenar efektif, namun pemahaman Ibu Maria Ulfa, profesinya sebagai pedangan baju di pasar wonokerto. Beliau sudah sekitar setengah tahun lebih menjadi nasabah BMT UGT Sidogiri Cabang Wonokerto. Beliau mengajukan pembiayaan untuk tambahan usahanya, maka BMT menyetujui untuk memberikan pembiayaan dengan cara menjual barang jaminan tersebut pada pihak BMT dan pihak BMT membeli seharga 50\% (lima puluh persen) dari harga pasar, dimana jual beli bersyarat tersebut merupakan salah satu persyaratan dari BMT UGT Sidogiri Cabang Wonokerto. Kepada anggota yang melakukan akad Bai'al-Wafa Ibu Maria Ulfa tidak merasa 
keberatan dengan syarat yang diajukan pihak BMT karena menganggap pihak BMT adalah bank Islam yang sudah banyak dipercaya masyarakat. Beliau juga sangat senang karena dapat melakukan pinjaman di BMT karena prosesnya yang mudah, dan juga bisa mengembangkan usahanya dengan bantuan pinjaman dari $\mathrm{BMT}^{29}$.

"Benar-benar bagus dengan adanya pinjaman seperti ini yang diberikan oleh Baitul Maal Wat Tamwil (BMT) Wonokerto. Sangat membantu kepada masyarakat, namun saya tidak paham apa Bai'ul Wafa itu? Yang penting saya bisa dapat modal" 30

Berdasarkan ilustrasi di atas, menunjukkan pemahaman masyarakat terhadap akad pembiayaan Bai'ul wafa masih belum maksimal, dengan pemahaman yang masih minim tentang akad tersebut, mereka tetap antusias, yaitu karena faktor kebutuhan dan bunga yang diberikan sangat rendah.

6. Manfaat Akad Pembiayaan Bai'ul Wafa terhadap Perkembangan Ekonomi Syari’ah di Masa Akan Datang

Dalam sistem ekonomi syariah kita mengenal prinsip jual beli (Murabahah, Salam, Ishtisna), bagi hasil (Mudharabah, Musyarakah), dan sewa (ijarah, IMBT). Dalam implementasinya pun juga diawasi oleh Dewan Pengawas Syariah (DPS) yang merupakan kepanjangan tangan dari Dewan Syariah Nasional (DSN) Bselaku otoritas yang mengeluarkan fatwa yang menjadi dasar pijakan bagi lembaga keuangan syariah dalam menjalankan usahanya. Dari sudut pandang emosional, mengamalkan ekonomi syariah berati mewujudkan seorang muslim yang kaffah karena syariah, akhlak, dan akidah merupakan tiga ajaran pokok dalam islam. Mengamalkan sistem ekonomi syariah memberikan keuntungan bagi seseorang dalam bentuk kepatuhan hambanya terhadap perintah-perintah Allah SWT. Salah satu perintah Allah SWT adalah bermuamalah dengan meninggalkan konsep riba.

Selain ditinjau dari aspek emosional, sistem ekonomi syariah juga memberikan keuntungan secara rasional. Keuntungan tersebut dapat dirasakan dengan cara bertransaksi melalui lembaga keuangan syariah seperti bank syariah, asuransi syariah dan lain-lain. Keuntungan tersebut antara lain: bahwa berdasarkan wawancara penulis dengan Kepala Cabang Baitul Maal Wat Tamwil (BMT) Cabang Wonokerto Malang. Bahwa proyeksi kedepan akad pembiayaan Bai'ul wafa mempunyai beberapa proyeksi jangka panjang dan insyaAllah akan menjawab tantangan perekonomian yang ilahiyah. Yaitu di antaranya. ${ }^{31}$

Di tengah perekonomian yang tidak stabil dan suku bunga Bank Indonesia yang

29 Wawancara dengan Maria Ulfa, Nasabah BMT UGT Sidigiri Cabang Wonokerto, 30 Mei 2016.

30 Wawancara dengan Maria, Nasabah BMT UGT Sidogiri cabang Wonokerto, 30 Mei 2016.

31 Wawancara dengan Yaskur, Kepala Cabang BMT UGT Sidogiri Cabang Wonokerto, 30 Mei 2016. 
berfluktuasi, skema murabahah ini sangat menguntungkan bagi nasabah individu maupun korporasi. Bagi nasabah individu terdapat kepastian besarnya penghasilan yang harus disisihkan untuk membayar angsuran setiap bulan. Bagi nasabah korporasi tentu akan lebih mudah dalam mengontrol keuangan operasionalnya dan menyusun budgeting perusahaan karena cash out flow yang dapat dihitung dengan pasti dikemudian hari.

1. Sistem bagi hasil yang lebih adil

Bank syariah juga mengenal skema pembiayaan berbasis bagi hasil atau biasa dikenal pembiayaan mudharabah dan musyarakah. Pembiayaan mudharabah adalah Akad kerjasama antara pemilik dana (shahibul maal) yang menyediakan seluruh kebutuhan modal dengan pihak pengelola usaha (mudharib) untuk melakukan kegiatan usaha bersama. Keuntungan dibagi menurut perbandingan (nisbah) yang disepakati. Pemilik modal tidak turut campur dalam pengelolaan usaha, tetapi mempunyai hak untuk melakukan pengawasan. Perbedaan yang paling utama antara skema mudharabah dengan musyarakah adalah porsi modal yang diberikan oleh pemilik dana. Dalam pembiayaan mudharabah seluruh modal (100\%) berasal dari pemilik dana, sedangkan pembiayaan musyarakah dana berasal kontribusi masing-masing pihak sesuai porsi yang disepakati (misal: 70\%: 30\%).

Dalam pembiayaan ini, bank akan membuat proyeksi bagi hasil (PBH) setiap bulan berdasarkan proyeksi omset usaha nasabah dan porsi bagi hasil yang disepakati. Selanjutnya setiap akhir bulan, nasabah akan menyampaikan deklarasi bagi hasil (rekap omset hasil usaha) yang didapat selama satu bulan. Atas dasar deklarasi tersebut bank akan menerima pembayaran bagi hasil yang didapat atas usaha nasabah.

2. Bebas biaya penalti jika dilakukan pelunasan sebelum Jatuh tempo

Bank syariah tidak membebankan biaya penalti dalam hal nasabah akan melakukan pelunasan sebelum jatuh tempo. Bahkan bank memungkinkan untuk memberikan diskon kepada nasabah berupa potongan margin dari yang seharusnya dibayar penuh menjadi lebih kecil, walaupun potongan margin tersebut tidak diperjanjikan di awal.

Beberapa point manfaat secara umum diterapkannya akad pembiayaan Bai' $u l$ wafa dalam sistem ekonomi syari'ah. Yaitu berdasarkan indek responsive masyarakat terhadap produk akad pembiayaan ini, yaitu sangat proyeksi untuk menjaga stabilitas perekonomian bangsa. Menurut Kepala Baitul Maal Wat Tamwil (BMT) Wonokerto Malang. ${ }^{32}$

\section{Simpulan}

1. Dalam penerapan akad pembiayaan Bai' al-Wafa para Ulama berpandangan bahwa Bai' al-Wafa sama dengan Rahn. Harta yang menjadi jaminan harus kembali kepada pemilik semula, akan tetapi 
karena sejak awal ditegaskan sebagai jual bali "Bai" maka pembeli dengan bebas memanfaatkan barang jaminan tersebut. Hanya saja muncul kesepakatan diantara kedua belah pihak bahwa barang yang menjadi jaminan tersebut tidak boleh dijual kepada pihak manapun kecuali kepada pihak penjual atau pemilik harta jaminan. Sedangkan kalau Rahn dalam Islam hanya merupakan jaminan utang, sementara barang yang dijadikan jaminan tidak dapat dimanfaatkan oleh pemberi hutang. Hal ini didasarkan pada hadits Rasulullah SAW dari Abu Hurairah yang diriwayatkan oleh al-Hakim Ibn Majah, Ibnu Hibban, dan al-Baihaki yang intinya menyatakan bahwa pemegang barang yang dijadikan jaminan utang pada prinsipnya tidak boleh memanfaatkan barang gadai tersebut, kecuali jika yang dijadikan jaminan utang itu adalah hewan ternak. Apabila pemberi utang memanfaatkan barang jaminan tersebut, maka hasil yang dimanfaatkan itu termasuk dalam kategori riba. Hal ini sejalan pula dengan sebuah hadist
Rasulullah SAW:"Setiap utang yang dibarengi dengan pemanfaatan (untuk pemberi utang) adalah riba" (HR. al-Bukhari).

2. Berdasarkan analisis teori efektivitas indek responsif masyarakat terhadap diterapkannya akad pembiayaan Bai' al-Wafa di Baitul Maal Wat Tamwil (BMT) UGT Sidogiri sangat cepat berkembang dan efektif, dikarenakan dengan akad tersebut masyarakat lebih mudah untuk mendapatkan layanan pembiayaan.

3. Manfaat dan proyeksi akad pembiayaan Bai' al-Wafa bagi perkembangan ekonomi syari'ah di masa akan datang tentang pembiayaannya lebih cepat perkembangannya dibanding ekonomi konvensional. Hal ini dipengaruhi karena beberapa sistem yang diterapkan ekonomi syari'ah yaitu di antaranya: angsuran pembiayaan yang tetap, sistem bagi hasil lebih adil. Bebas biaya penalti jika dilakukan pelunasan sebelum Jatuh tempo.

\section{DAFTAR PUSTAKA}

\section{Buku}

Afandi, Yazid. Fiqih Muamalahdan implementasinya dalam lembaga keuangan syariah. Yogyakarta: Logung Creative Design, 2009.
Arfan, Abbas. 99 kaidah fiqih muamalah kulliyyah (tipologi dan penerapannya dalam ekonomi islam dan perbankan islam. Malang: Uin-maliki press, 2013. 
Dahlan Al-Barry, Kamus ilmiah populer. Yogyakarta: Arkola, 2001.

Departemen Pendidikan Nasional. Kamus Besar Bahasa Indonesia. Jakarta: Balai Pustaka Cetakan Pertama, 2001.

Dikutip dari bukunya Arif Sidharta. "Refleksi tentang hukum-pengertian-pengertian dasar dalam teori hukum”. Bandung: Citra Adtya Bakti, 1996.

Hirsanuddin. Hukum Perbankan Syariah di Indonesia (Pembiayaan Bisnis Dengan Prinsip Kemitraan. Yogyakarta: Genta Press, 2008.

HS, Salim. Penerapan Teori Hukum Pada Penelitian Tesis Dan Disertasi. Jakarta: RajaGrafindo Persada, 2013.

Ibrahim, Johnny. Teori \& Metodologi penelitian hukum Normatif. Edisi Revisi. Cetakan Ke-dua. Malang: Banyumedia Publishing, 2006.

Komariah. Hukum Perdata. Malang: UMM University, 2002.

Manan, Abdul. Reformasi Hukum Islam di Indonesia. Jakarta: RajaGrafindo Persada, 2006.

Muhammad. Lembaga-Lembaga Keuangan Umat Kontemporer. Yogyakarta: UII Press, 2000.

Simanjuntak, PNH. Pokok-pokok Hukum Perdata di Indonesia. Jakarta: Djambatan, 2009.

Subekti. Hukum perjanjian. Jakarta: Intermasa, 2001.

Suratmaputra, Ahmad Munif. Filsafat Hukum Islam Al-Ghazali: Mashlahah-
Mursalah dan Relevansinya dengan Pembaharuan Hukum Islam. Jakarta: Pustaka Firdaus, 2002.

Syafi'I, Antonio Muhammad. Bank syariah dari teori ke praktek, Jakarta: Gema insani press, 2001.

Tadjuddin, Moh. Orisinalitas gagasan dalam penulisan tesis dan disertasi. Bandung: Program Pasca Sarjana Universitas Padjajaran, 2000.

\section{Jurnal}

Ardiansyah, Dimas. "Implementasi pembiayaan dengan akad mudharabah (study pada bank syariah di kota Malang”. Jurnal Fakultas Ekonomi Universitas Brawijaya Study Ekonomi Syariah, 201.

\section{Naskah Internet}

Baidlowi, Ahmad. "Intisari Amaliyah Ulama Fiqih”. http://restuandrian.blogspot. com/2011/12/pengertian-dan-hukumtaqlid.html. Diakses 26 Mei 2016.

Musthofa, Muhammad Asim. "Al Hilah, Melakukan Rekayasa Terhadap Hukum Allah". https://almanhaj.or.id/2890-alhilah-melakukan-rekayasa-terhadaphukum-allah.html. Diakses 21 April 2016.

Suheri. "Fatwa Tentang Dana Pensiun Syariah". https://suherilbs.wordpress. com/?ref=spelling. Diakses 21 April 2016. 
Peraturan perundang-undangan

Kitab undang-undang hukum perdata (KUHPerdata).

Undang-undang Nomor 10 Tahun 1998 tentang Perbankan.
Undang-undang Nomor 21 Tahun 2008 tentang Perbankan Syari'ah.

Al-qur'an dan al-hadist.

Fatwa hukum bisnis syar'ah.

Kitab hukum ekonomi syari'ah (KHES). 